\title{
Remedying the obsolescence of digitised surveys of medieval sources. Narrative Sources and Diplomata Belgica
}

\author{
by Jeroen Deploige, Bert Callens, Philippe Demonty and Guy De Tré ${ }^{1}$
}

High level and original basic research in the field of medieval studies is extremely dependent upon reliable heuristic instruments as well as easy access to primary source materials. Within the Humanities, it is the medievalists in particular who have pioneered the use of IT for the editing, description and analysis of primary sources. The projects Narrative Sources and Nouveau Wauters - the latter today called Diplomata Belgica - thus very early on resulted in the development of innovative electronic databases which have proved their usefulness and reliability for more than a decade, and which have had a significant impact on the progress of the study of the medieval Low Countries. An argument which was often used in the 1990s, when scholars and publishers chose to publish new heuristic instruments electronically - whether on CD-Rom or on the Internet - was that in this way the ageing of such instruments could be prevented because of the possibility of continuous updating. Paradoxically, it now seems that electronic publications are among the first to suffer from problems of sustainability due to the rapid evolution of electronic media. Today, both Narrative Sources and Diplomata Belgica are seriously subject to what the Dutch historian Jan Romein has termed the 'law of the retarding lead'. ${ }^{2}$

The two databases are not, however, facing exactly the same problems of obsolescence. Narrative Sources, which was very recently moved under the auspices of the Belgian Royal Historical Commission, has been subjected to a project in which completely new software has been developed. The main challenge to this database is therefore the question of how to make and keep its contents up to date. Diplomata Belgica, on

\footnotetext{
1 The research referred to in this article was made possible thanks to funding by the Belgian Royal Historical Commission and by the Flemish Hercules Foundation. Except for P. Demonty, who is contracted by the Royal Historical Commission, all authors are attached to Ghent University.

2 J. RomeIn, 'De dialektiek van den vooruitgang', in Het onvoltooid verleden. Kultuurhistorische studies (Amsterdam: Querido, 1937), pp. 9-64.
} 
the other hand, has long been one of the Historical Commission's showpieces. But whereas this dataset can certainly be considered remarkably up to date, it still lacks a serious database system and accessibility on the internet. In this article, we will briefly survey the histories and perspectives of both tools and offer a first glimpse of the recently approved project entitled Sources from the Medieval Low Countries (SMLC), which aims to offer new remedies to cope with the problem of sustainability and to provide scholars with solutions that correspond to the most recent needs in medieval studies.

\section{Narrative Sources}

The initiative for the Narrative Sources project originated in 1986 at the Universities of Ghent and Leuven. ${ }^{3}$ The aim was to develop an exhaustive inventory of all the narrative sources from the Southern Netherlands written between c. 600 and c. 1500, both in Latin and in the vernacular, and to supply this 'Belgian' information to the huge, and to date still unfinished, international project of the Repertorium Fontium Historiae Medii Aevi. ${ }^{4}$ 'Narrative' sources were understood to include all texts dealing with the past in a narrative mode, ranging from chronicles, annals and saints' lives to genealogies and historical poems. Until the 1960s, these kinds of texts remained rather neglected in traditional scholarship, but due to the emerging disciplines of the history of mentalities and cultural history, they resumed their importance for medieval studies. Nevertheless, a complete inventory of the narrative sources of the Southern Low Countries was still lacking.

Initially, there was no clear intention to develop a database to be published on the internet. It was only after the beginning of the 1990s that this option surfaced more explicitly. The fact that the data had not been collected from the onset with a view to a decent and coherent database system can still be felt today. When the first version of the database was launched, freely accessible, on the internet in January 1997, it was still one of the first of its kind in the field of medieval studies. The response from the majority of users was very positive. ${ }^{5}$ Although the

3 The founding committee consisted of L. Milis at Ghent University and J. Goossens and W. Verbeke at the Catholic University of Leuven. The project was realised with funds from the Research Foundation-Flanders (FWO).

4 Repertorium Fontium Historiae Medii Aevi primum ab Augusto Potthast digestum, nunc collegi historicorum e pluribus nationibus emendatum et auctum (Rome: Istituto Storico Italiano per il Medio Evo, 1962-...), 10 vols and 1 fascicule published so far (letters A till T).

5 Some announcements and reviews: J. DePloige, 'Narrative Sources: défis et possibilités d'un outil interactif pour hagiologues', Le médiéviste et l'ordinateur, 34 (1996-97), pp. 16-20 (URL: http://lemo.irht.cnrs.fr/34/mo3404.htm); S. CoRBELLINI, 'Medievistica in rete: Bibliotheca Neerlandica Manuscripta (Biblioteca Universitaria, Leida) e Narrative Sources (Università di Gand e Università Cattolica di Lovanio), in Medioevo in rete tra 
information in the database was, and still is, not entirely perfect, this was readily forgiven because the database gave immediate access to a 'workin-progress', and because those who used it quickly discovered that it offered them completely new research possibilities. However, despite repeated invitations and a few remarkable exceptions notwithstanding, the editors of the database never received much user feedback in the form of corrections, additions, or submissions of completely new records. Any kind of 'wikification' was consequently never realised. The limited annual updates made since 1997 have remained, for the most part, the result of contributions by the original collaborators on the project. Yet one very important new step was taken between 2001 and 2003, when the geographical scope of the database was extended to the entire territory of the medieval Low Countries, thanks to the addition by a research team at the University of Groningen ${ }^{6}$ of the updated information originally gathered in 1981 by M. Carasso-Kok in her printed Repertorium van de verhalende historische bronnen uit de Middeleeuwen. ${ }^{7}$ As a result, the database contained no less than c. 2150 records, which described the listed narrative sources by means of 23 separate fields, though stopping short of full texts.

However, despite its success, the original Narrative Sources database quickly became obsolete both because of its software and, especially regarding the information on the Southern Low Countries, because of its content. The first software used, SilverPlatter, was far from user-friendly and discouraged the optimal use of its multiple yet very complicated search facilities. ${ }^{8}$ Moreover, the procedures to update the database were so cumbersome that in the last five years no additions or corrections have been made. Meanwhile, the Belgian Royal Historical Commission already took a first step to remedy the looming obsolescence of Narrative Sources by taking on the role of academic publisher of the database and by ordering the development of entirely new and custom-made software

ricerca e didattica, ed. by $\mathrm{R}$. GRECI (Bologna: CLUEB, 2002), pp. 63-74; E. vAN Houts, 'Review of The Narrative Sources from the Medieval Low Countries, Universities of Ghent, Leuven and Groningen (http://www.narrative-sources.be)' and J. DePLoIGE, 'Editor's Response', Reviews in History (Jan. 2007), review no. 569 (URL: http://www.history.ac.uk/ reviews/paper/vanhouts.html).

${ }^{6}$ On this extension, financed by the Netherlands Scientific Organisation (NWO), see the article by the project leader at the University of Groningen: R. NIP, 'Changing Demands, Changing Tools. A Survey of Narrative Historical Sources, Written during the Middle Ages in the Northern Low Countries', in Medieval Narrative Sources. A Gateway into the Medieval Mind, ed. by W. Verbeke, L. Milis and J. Goossens (Leuven: Leuven University Press, 2005), pp. 1-20.

7 M. CARASSO-KoK, Repertorium van verhalende historische bronnen uit de Middeleeuwen. Heiligenlevens, annalen, kronieken en andere in Nederland geschreven verhalende bronnen, Bibliografische Reeks van het Nederlands Historisch Genootschap, 2 (s-Gravenhage: Martinus Nijhoff, 1981).

${ }^{8}$ An introduction into search strategies was offered in J. Deploige, Narrative Sources. User's Guide. Gebruikersgids. Guide de l'utilisateur. Vs. 3.1 (Gent-Leuven-Groningen, 2003). 


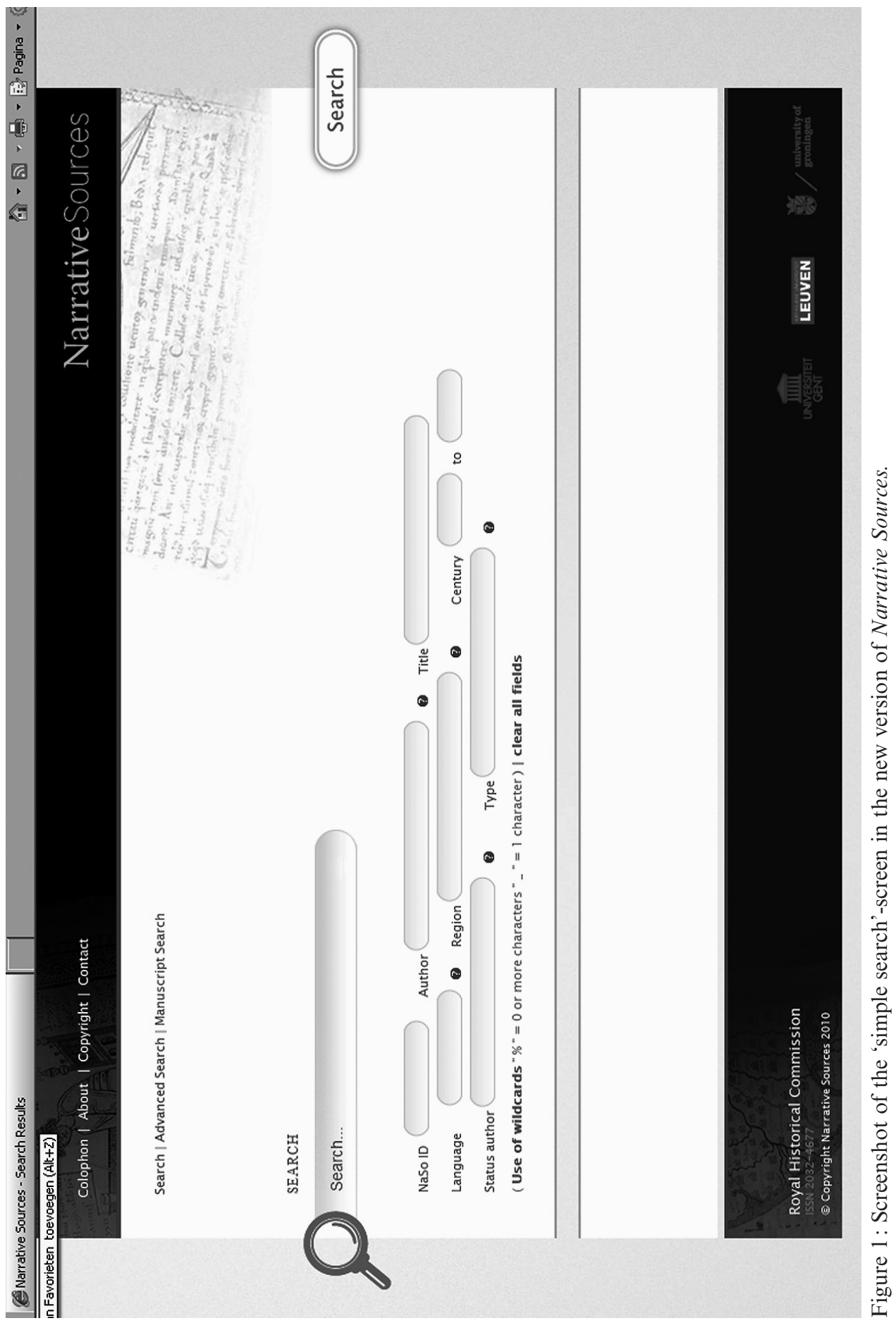


through a Technology Transfer Contract made with Ghent University. ${ }^{9}$ This software, developed between 2008 and 2009 and publicly operational since spring 2010, offers a new and powerful database structure for the content of Narrative Sources as well as a special content management module (with password-secured access) which makes it possible to update the database directly online. ${ }^{10}$ It also allows for the insertion of hyperlinks, for example to full text editions or descriptions of manuscripts elsewhere on the internet. ${ }^{11}$

Compared with the first database version, the new Narrative Sources is trying above all to enhance the comfort of the average user through its extensive, transparent and user-friendly search facilities. After having made a choice between the Dutch or the English versions of the database, the user is offered three different search screens. First, there is the 'simple search' option, which allows searching for descriptions of narrative sources by using (a combination of) the most common attributes such as name of the author, type of the source, century, region etc. This option is estimated to cover up to 90 percent of the search requests posted by scholars. The second, 'advanced search'-screen offers the possibility of searching for narrative sources with very specific search queries which users can construct themselves with the help of Boolean operators. This screen thus allows for very specific questions to the database, yet without any IT or database knowledge being required. The third search method gives users the option to search for manuscripts containing narrative sources instead of for narrative sources as such.

This last search method is one of the main results of the fact that the new stage in the Narrative Sources project also provided an excellent opportunity to reorganize the structure and the content of the database. The original Narrative Sources remained an exclusively text-

${ }^{9}$ Directors of this project were J. Deploige (Department of Medieval History) and G. De Tré (Research Group of Database, Document and Content Management). B. Callens was contracted as scientific collaborator. See also J. Deploige, B. Callens, G. De Tré, 'Een nieuwe toekomst voor het online repertorium The Narrative Sources of the Medieval Low Countries', in Herinnering in geschrift en praktijk in religieuze gemeenschappen uit de Lage Landen, 1000-1500, ed. by J. Deploige, B. MeiJns and R. NiP (Brussels: Koninklijke Vlaamse Academie van België voor Wetenschappen en Kunsten, 2009), pp. 183-97.

10 The Narrative Sources from the Medieval Low Countries. De verhalende bronnen uit de middeleeuwse Nederlanden (Brussels: Royal Historical Commission, since 2009 - URL: http ://www.narrative-sources.be).

${ }^{11}$ See e.g. Monumenta Germaniae Historiae digital (München: Bayerische Staatsbibliothek - URL: http://www.dmgh.de); Gallica (Paris: Bibliothèque Nationale de France - URL: http://gallica.bnf.fr/); Bibliotheca Neerlandica Manuscripta (Leiden: Universiteitsbibliotheek Leiden, since 1991 - URL: http://www.bibliotheek.leidenuniv.nl/collecties/bijzonder/handschriftenarchievenbrieven/bnm.html); Medieval Manuscripts in Dutch Collections (Den Haag: Koninklijke Bibliotheek - URL: http://www.mmdc.nl); Bibliotheca Hagiographica Latina manuscripta. Index électronique de la Bibliotheca Hagiographica Latina et des Catalogues de manuscrits hagiographiques latins (Brussel, Louvain-la-Neuve: Centre de recherches «Hagiographies» des F.U.N.D.P. à Namur \& Société des Bollandistes: 1998 - URL: http://bhlms.fltr.ucl.ac.be/). 
oriented database: it provided a detailed survey of identifiable texts, without paying attention to the composition of the manuscripts in which these textual units have been transmitted and preserved. However, many types of narrative and memorial texts - necrological, historiographical, hagiographical, liturgical and even diplomatic - were often gathered in miscellanies. These have rarely been studied in their entirety nor has it been sufficiently recognised that they could have been assembled together with a purpose. ${ }^{12}$ For the Low Countries, this problem has recently been brought to light by the international three-year pilot project "Memory in word and deed. An analysis of the transmission in manuscript as reflection of the practice of remembering in religious communities (c. 11001500)". ${ }^{13}$ The motives of the authors and scribes who gathered together such (memorial) miscellanies, and the function of these manuscripts within the medieval culture of remembrance, deserve further research, one to which the above-mentioned pilot project has already given an important impetus. For only such an approach can lead to a better understanding of the transmission and the real function of these texts. ${ }^{14}$

By way of example, we can look at the important manuscript 425 from the City Library of Bruges from the early sixteenth century, originally composed in the Cistercian abbey of Les Dunes, in which it is noticeable that it brings together three groups of historiographical and hagiographical texts: a number of high and late medieval narratives related to the abbey of regular canons of Watten in the County of Flanders, two highly important texts originating from the Cistercian abbey of Villers in Brabant, and a series of sources, originally compiled by John Gielemans in the years 1483-5, informing us on the spread of the late-medieval Windesheim movement in Brabant. In the new Narrative Sources system, it thus becomes possible to reconstruct the composition of this kind of manuscript, in order to analyze immediately which texts were copied and hence used and read together in one and the same codex. The example further shows that such an approach will also help us to discover a lot of

12 See e.g. the pioneering insights in The Whole Book: Cultural Perspectives on the Medieval Miscellany, ed. by S. G. Nichols and S. Wenzel, Recentiores: Later Latin Texts and Contexts, 6 (Ann Arbor: The University of Michigan Press, 1996); Imagining the Book, ed. by S. Kelly and J. J. Thompson, Medieval Texts and Cultures of Northern Europe, 7 (Turnhout: Brepols, 2005); J.P. GUMBERT, Codicologische eenheden - opzet voor een terminologie, Mededelingen van de Afdeling Letterkunde, Nieuwe Reeks, 67:2 (Amsterdam: Koninklijke Nederlandse Academie van Wetenschappen, 2004).

13 This project, funded by NWO (2006-08) and directed by R. Nip at the University of Groningen in collaboration with J. Deploige at Ghent University, has already resulted in the volume Herinnering in geschrift en praktijk, ed. by DePloige, MeiJns and Nip (see n. 9). More publications are planned.

14 See e.g. S. FolKERTs, 'Het handgeschreven boek als platform voor identiteitsvorming in de religieuze gemeenschap', in Herinnering in geschrift en praktijk, ed. by DePLOIGE, MeIJns and Nip (see n. 9), pp. 71-8 or T. SNIJDERS, Ordinare et communicare. Redactie, opmaak en transmissie van hagiografische handschriften in kloosters uit de Zuidelijke Nederlanden (Ghent: unpublished doctoral dissertation, 2009). 
Fol. 1r-12v: Ebrardus. Cronica monasterii Guatinensis - NaSo C011

Fol. 13r-21v: Miraculum de quodam Guatinensi religioso per sanctum Donatianum ab egritudine sua sanato - NaSo I

Fol. 21v-22r: Ex legenda sancti Richarii - NaSo I

Fol. 22v: Ex legenda sancti Arnulphi Suessionensis episcopi in Aldenborch quiescentis - NaSo $\mathbf{H 0 0 9}$

Fol. 22v-23r: Miraculum quod accidit in monasterio Watinensi in nocte beate Agnetis virginis - NaSo I

Fol. 23r-23v: De incendio ecclesie - NaSo I

Fol. 23v-24r: [Consequences of the thunderbolts, in 1124, in St.-Omer and in Watten] - NaSo I

Fol. 25r-30v: Tabularis epylogus prepositorum ecclesie beate Marie Brugensis NaSo $/$

Fol. 34r-58v: Cronica abbatum Vilariensium - NaSo C010-J179*

Fol. 58v-109r: Liber de gestis virorum illustrium monasterii Vilariensis - NaSo G078*

Fol. 112r-139r: Liber de origine monasterii Viridis Vallis in Zonia - NaSo H023*

Fol. 139r-144v: Planctus venerabilis fratris Guilhelmi Iordani, canonici regularis Virdidis Vallis, super obitu Fratris Iohannis de Speculo, dyaconi eiusdem cenobii - NaSo G167*

Fol. 144v-185r: Primordiale monasterii canonicorum regularium Rubee Vallis in Zonia - NaSo /*

Fol. 185r-187v: Carmina Christiani de Veris - NaSo /*

Fol. 188r-196v: Tractatulus de origine monasterii septem Fontium - NaSo G162*

* = parts of John Gielemans's Novale sanctorum - NaSo J206

Figure 2: Contents of Bruges, Stadsbibliotheek Biekorf, ms. 425 (early sixteenth century - olim abbey of Les Dunes) $)^{15}$.

texts that have not yet been inventoried so far (Figure 2). Indeed, several of the components of this manuscript are not yet dealt with in Narrative Sources.

That it became technically possible to develop such new ways of storing information and to make it searchable in an adequate manner is due to the fact that, contrary to its predecessor, the new Narrative Sources is based on a complex relational database structure ${ }^{16}$. The old data model was still very simple. Every single description of a narrative source constituted one separate entity, containing 22 different attributes

15 For a complete description see A. De PoORTER, Catalogue des manuscrits de la Bibliothèque publique de la ville de Bruges, Vol 2 (Gembloux-Paris: J. Duculot-Les Belles lettres, 1934), pp. 478-81. For the date of this manuscript, see V. HazEBrouck-Souche, Spiritualité, sainteté et patriotisme. Glorification du Brabant dans l'œuvre hagiographique de Jean Gielemans (1427-1487), Hagiologia. Etudes sur la Sainteté en Occident, 6 (Turnhout: Brepols, 2007), pp. 36-37, n. 8.

16 E. Codd, 'A Relational Model of Data for Large Shared Data Banks', Communications of the ACM, 13:6 (1970), pp. 377-87 (reprinted in Communications of the ACM, 26:1 (1983), pp. 64-69); G. De Tré, Principes van databases (Amsterdam: Pearson, 2007). 


\begin{tabular}{|l|}
\hline \multicolumn{1}{|c|}{ Narrative Source } \\
\hline Abstract \\
Author \\
Century \\
Context \\
Desiderata \\
Editions \\
Explicit \\
Incipit \\
Identification \\
Influence \\
Language \\
Literature \\
Manuscripts \\
Contributor \\
Redaction \\
Region \\
Sources \\
Status of author \\
Title \\
Translations \\
Type \\
Last Update \\
\hline
\end{tabular}

Figure 3: The old Narrative Sources data structure.

(Figure 3). This primitive structure, similar to traditional worksheets, offered only limited possibilities to store, query and present the data. It resulted in innumerable inconsistencies and a great amount of redundancy.

The new Narrative Sources application, on the other hand, uses a custom-designed relational database system in which data is structured in several different entities, each representing a logical data unit with its own specific attributes, which are all related with each other through predefined ways. For example, where in the old model an author and his status are attributes of a narrative source, the new model contains a separate entity for authors and their respective attributes, and this entity 'author' is subsequently related to another entity called 'narrative source'. In exactly the same way the information on manuscripts is now isolated as a separate entity. Even while this new data model seems to be undeniably more complex at first sight, it is precisely this complex structure that allows for serious improvements in flexibility and user-friendly access to the data as well as efficiency in data management (Figure 4). The complexity of this data model remains hidden behind the web interface and is therefore invisible to the end-user. The latter will also take great comfort from the fact that thanks to this relational structure, he or she will have more confidence in the correctness of his or her search results. This is not as obvious as it may seem, because adding or changing data 


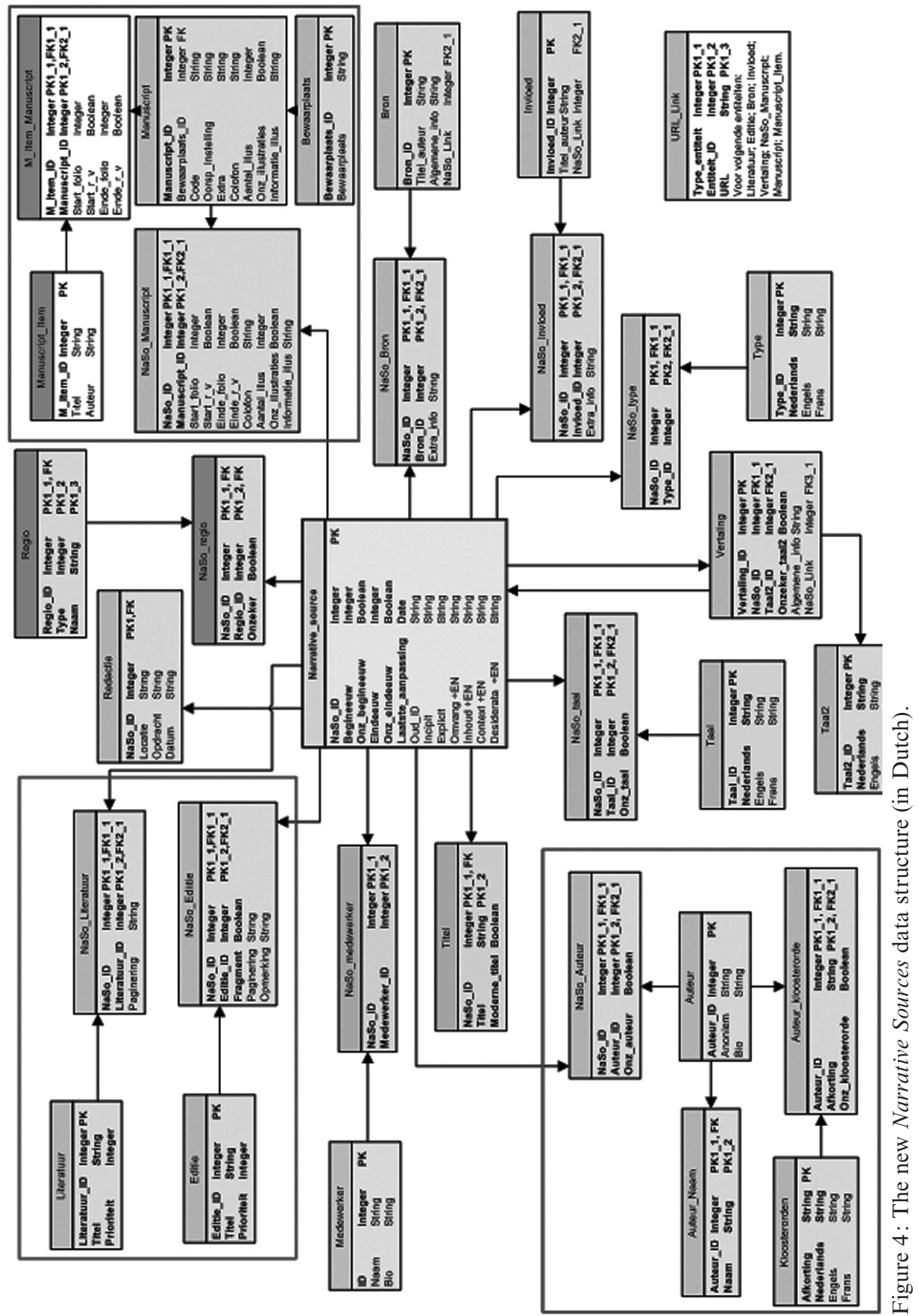


in a database is often the work several data managers, and mistakes are easily made when working with large quantities of data. The relational database technology offers a series of techniques which makes a dataset less error-prone, and requires less effort for the data managers to maintain a consistent dataset.

However, despite the fact that it is not an exaggeration to say that thanks to its database software, Narrative Sources is now well-prepared to provide at least another decade of support to medieval studies of the Low Countries, there is still an essential need to completely update the actual contents of the database. New research carried out since the 1990s has revealed that there are hundreds of remaining texts which still need to be inventoried, that the descriptions of many late medieval chronicles are seriously inadequate, that the massive amount of secondary literature published since the mid-1990s remains to be incorporated, and so on. Furthermore, all the essential information on manuscript traditions which the newly designed database structure allows for, still needs to be collected systematically in order to be able to answer new research questions effectively. At least 1,500 manuscripts remain to be documented in detail and need to have hyperlinks added to other recent catalogues.

\section{Diplomata Belgica}

The project of the Diplomata Belgica originated in the mid 1980s, when the Belgian Royal Historical Commission proposed a complete and computerised revision of the well-known Table chronologique des chartes et diplômes imprimés concernant l'histoire de la Belgique. This heuristic instrument had been published in eleven volumes between 1866 and 1971 under the original editorship of Alphonse Wauters and provided textual analyses of all edited charters from before $1350 .{ }^{17}$ The new project designed by the Royal Historical Commission led to a close collaboration with the Comité belge du dictionnaire latin médiéval, and with the former Cetedoc (Centre de Traitement électronique des Documents) at the University of Louvain-la-Neuve. ${ }^{18}$ In 1997 it resulted in the publication of the CD-Rom Thesaurus diplomaticus, which was commercially distributed by Brepols Publishers. ${ }^{19}$

17 Table chronologique des chartes et diplômes imprimés concernant l'histoire de la Belgique, ed. by A. WAUters et al. (Brussels: Commission Royale d'Histoire, 1866-1971).

18 On this project: G. Declercq, Ph. Demonty, K. Naessens, G. Triffin, 'L'informatisation de la 'Table chronologique' d'A. Wauters. Méthodologie du nouveau répertoire des documents diplomatiques belges antérieurs à 1200', Bulletin de la Commission Royale d'Histoire, 153 (1987), pp. 223-302.

19 Thesaurus diplomaticus, ed. by P. Tombeur et al. (Turnhout: Brepols, 1997 CD-rom). 


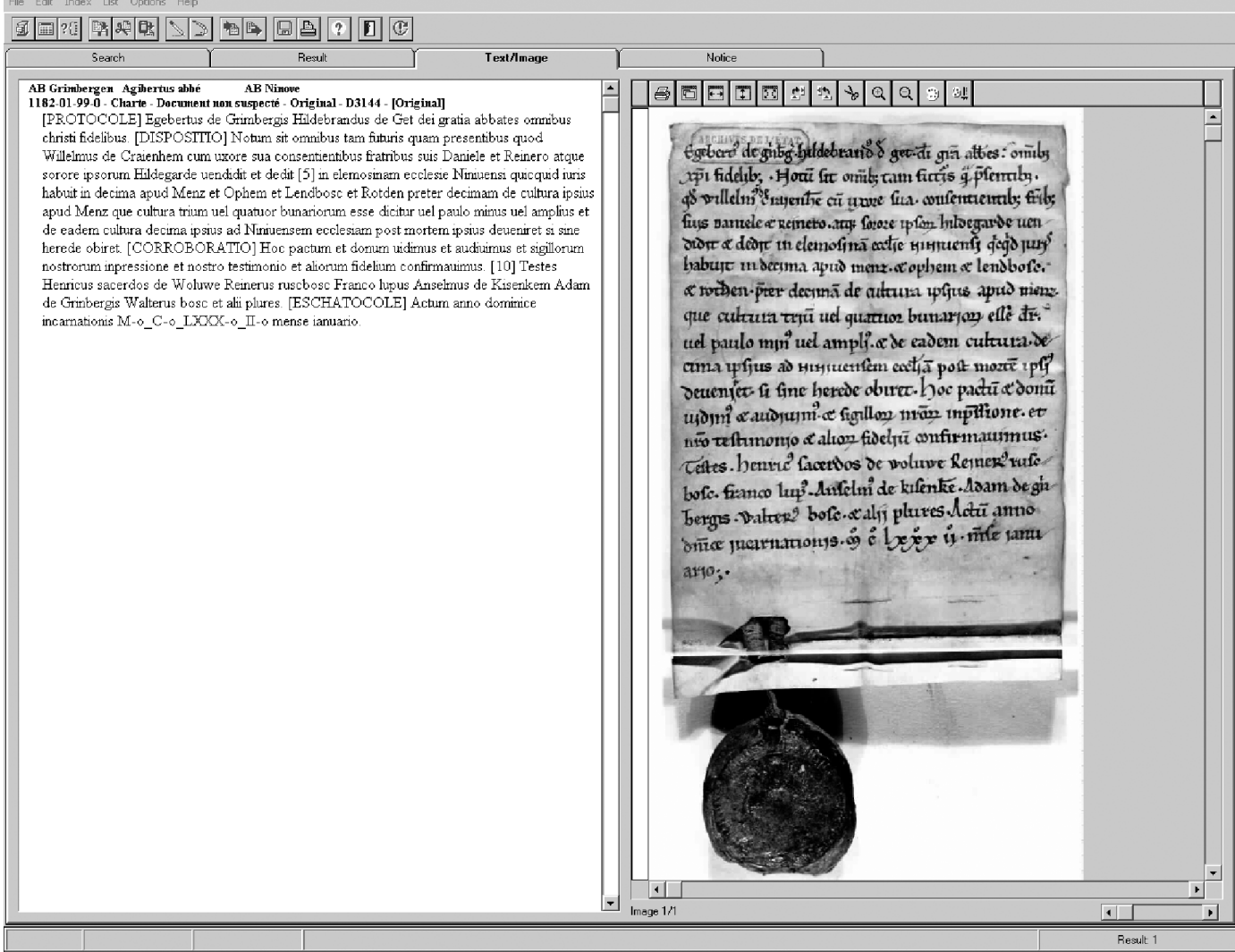

Figure 5: Screenshot from the Thesaurus diplomaticus, containing a full text edition and a photograph.

The Thesaurus diplomaticus offers an analytical survey of all diplomatic sources written (in Latin) between circa 640 and 1200 (various types of charters and deeds), edited or still unpublished, and issued by both natural persons and legal bodies from the medieval Southern Low Countries. In total, the Thesaurus contains 12,745 descriptions of documents (with dates, abstracts, secondary literature and archival information), of which there are more than 5,807 with full text and 2,189 with a photograph of the original charter. ${ }^{20}$ Since its publication, the Thesaurus diplomaticus has had a major influence on a variety of research, especially in the fields of traditional political, institutional and economic history.

Thirteen years later, however, this CD-Rom has already become outdated for several reasons. Firstly, Philippe Demonty, being contracted by the Royal Historical Commission to continue the Diplomata Belgica project, has collected thousands of new data since 1997 for the correction

20 See also Ph. Demonty, 'Le Thesaurus diplomaticus, un instrument de travail pour une nouvelle approche en diplomatique médiévale', in La diplomatique urbaine en Europe au Moyen Âge, ed. by Th. DE Hemptinne, W. Prevenier, Studies in Urban Social, Economic an Political History of the Medieval an Early Modern Low Countries, 9 (Leuven and Apeldoorn: Garant, 2000), pp. 123-32. 
and improvement of the collection, covering the period 640-1200 as well as for the subsequent decades between 1200 and 1250. Hence for this last period, the Commission currently has at its disposal a dataset containing 20,591 extra descriptions, not only of Latin but also of Old French charters from the Southern Low Countries. 12,167 of these are offered in full text and, for the moment, 2,189 are with a photograph. Demonty is currently still busy adding more information to this collection, with particular attention to the further analysis of unedited documents kept as originals or as copies in cartularies. However, this new important data set, which offers almost a threefold increase of the number of data in the Thesaurus diplomaticus, is not yet accessible for research purposes.

In the meantime, it turns out that even the CD-Rom Thesaurus diplomaticus has become technically outdated. Search possibilities are limited according to today's norms. The fields currently searchable, for instance, do not give access to all of the information such as secondary literature or archival details. Searching in the Thesaurus also requires a lot of prior knowledge of the collection, and statistical analyses, for which the data offers several opportunities, remain very difficult. ${ }^{21}$ Today, anno 2010, one can even say that CD-Roms themselves have become completely obsolete carriers of digital information, not least because they are not made for continuous updating. Adding new records, corrections or recent literature and removing documents is impossible without continuous and expensive new issues of the CD-Rom. This problem is especially significant for the updating of the material that is already published in the Thesaurus diplomaticus.

The extension of the scope of the Thesaurus diplomaticus to the thirteenth and fourteenth centuries confronts us with yet another major problem. These centuries were increasingly prolific in their production of charters. One can think here for example of the growing number of episcopal documents. This situation makes it unfeasible to continue the updating process on the basis of strict chronological criteria, by moving up, for example, from 1200 to 1250, and then from 1250 to 1300, etc. Such a procedure would urge data managers to go back and forth continuously between the same cartularies, archives or collections (which would also give headaches to the archivists). Therefore the future work of inventorying needs to be done, not within fixed chronological limits, but by focusing on complete and consistent collections of documents or archival series. As a result, the database system too must become more open to the publication of work-in-progress in order to provide the academic community as quickly as possible with new and reliable information.

21 For an interesting, exceptional example, see nonetheless S. VANDERPUTTEN, 'Transformations in Charter Production and Preservation During the "Iron Age" (Tenth-Early Eleventh Centuries): Some Evidence From Northern France and the Southern Low Countries', Jaarboek voor Middeleeuwse Geschiedenis, 7 (2004), p.7-30. 
Finally, it should be noted that in 1997 the Thesaurus diplomaticus was still one of the first databases of its kind in the field of medieval diplomatics. Ten years later, however, one can already find plenty of comparable instruments and useful additional information on the internet: on-line inventories of historical archives, digital reproductions of seals or full-text editions, on-line databases such as the Chartes originales antérieures à 1121 conservées en France, etc. ${ }^{22}$ There is even still much more information to come, as the Belgian State Archives are also planning important digitisation projects of their medieval archival collections. This is another reason why it has become essential to develop a database system with unlimited possibilities of online cross-referencing.

The Royal Historical Commission has been extremely aware of the importance of finding a new way of publishing its huge data set electronically, while at the same time being convinced of its duty to publish this collection on the internet for free consultation as it has been developed with public funding. Since the Commission does not have the expertise to realise such a decent database system it has expressed its willingness to share the Diplomata Belgica dataset with the Narrative Sources team, as the members of this group had already proven their expertise and technical skills in their recent development of a new electronic infrastructure for Narrative Sources. A comparable database system would completely fulfil the requirements for Diplomata Belgica: it would offer an online relational structure, tailored to the needs of both end-users and contentmanagers, and it would allow for a continuous publication of work-inprogress.

\section{A Herculean Task?}

The idea of developing a project in which the various concerns about the obsolescence of both Narrative Sources and Diplomata Belgica could be dealt with, had to cope with two different problems. The first problem was conceptual. The second problem was how to finance it.

The new database system of Narrative Sources is fully programmed in accordance with international database standards and with the open source database software MySQL, one of the most used non-commercial systems. Its open and scalable multi-tier client-server architecture makes it perfectly possible to fully integrate other data sources or to share data with other (independently managed) databases. How useful would it be to develop one single integrated data system for Narrative Sources and Diplomata Belgica? Both data sets certainly have much in common and even their contents offer a lot of comparable attributes: references to liter-

22 This database was recently launched on the website of the French Centre national de ressources numériques Telma (URL: http://www.cn-telma.fr). 


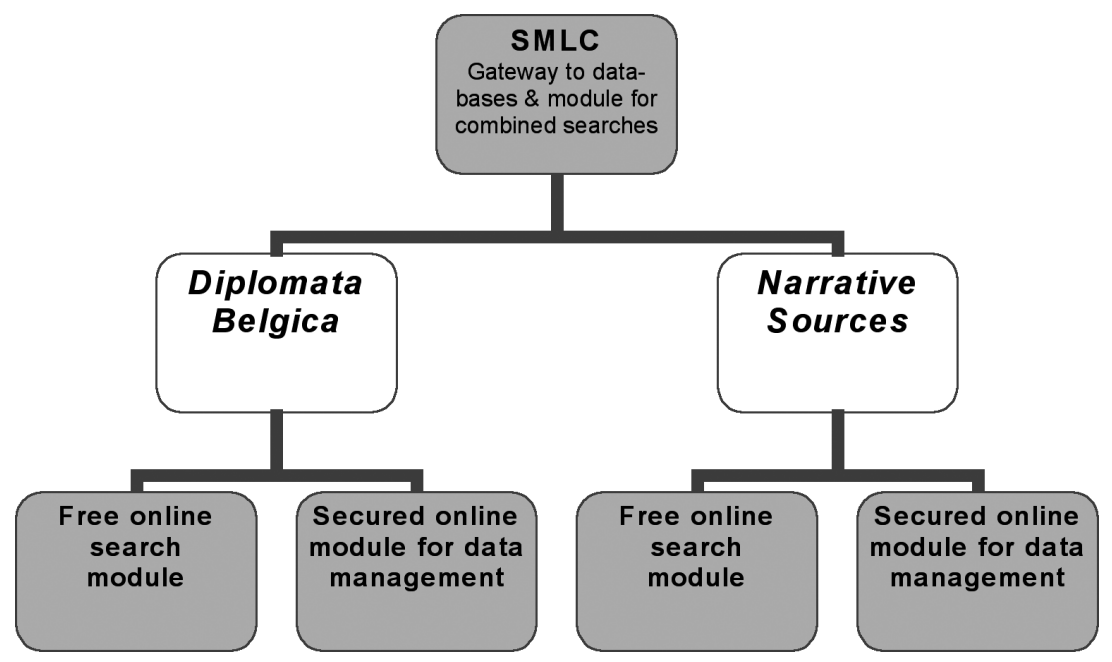

Figure 6: Structure of the multiple database system Sources from the Medieval Low Countries.

ature, to editions, to manuscripts, to places of redaction, etc. However, both data collections remain very dissimilar as to other kinds of information, even when they coincidentally treat the same medieval source. An example may clarify this. The letter collection of bishop Stephen of Tournai dating from the end of the twelfth century, which constitutes an important source for ecclesiastical history, appears in both databases. ${ }^{23}$ In Narrative Sources, the whole collection is inventoried as one single work counting 67,627 words and dated between 1158 and 1200. In the database Diplomata Belgica, however, this same corpus is divided into some 150 distinct letters, each of which is dated and analysed separately and provided with a full text edition. It may be clear that the principles of description, of dating and of analysing thus differ considerably between diplomatic and narrative sources. Another important difference between Diplomata Belgica and Narrative Sources is the fact that the first is offering its information in French, while the latter is giving the user the choice between Dutch and English.

A single, integrated database structure for both Diplomata Belgica and Narrative Sources is therefore not a suitable solution. That is why the concept of a multiple database system, entitled Sources from the Medieval Low Countries (SMLC), was developed for the realisation of which a consortium composed of scholars from Ghent University, the Royal Historical Commission, the Belgian State Archives and representatives

\footnotetext{
23 Lettres d'Etienne de Tournai, ed. by J. Desilve (Valenciennes and Paris: Lemaitre, 1893); W. Ysebaert, 'Cinq lettres inconnues d'Etienne d'Orléans (1128-1203)', Sacris erudiri, 45 (2006), pp. 353-78.
} 
from the universities of Leuven, Groningen and Utrecht was set up. The Flemish Hercules Foundation, which organised a call for proposals for the development of medium-sized research infrastructure, generously decided to fund this plan.

The idea behind SMLC is that it will unite two underlying and separate databases: Diplomata Belgica and Narrative Sources. Each database will contain its own online module for consultation and its own online application for data management and updating. However, SMLC will also offer one extra module for combined searches in both these databases (Figure 6). ${ }^{24}$ Diplomata Belgica and Narrative sources share a number of fields containing very comparable information: institution where the source is written, diocese or secular principality in which the source originated, religious order of the author, language, chronological period, etc. As medieval scholars recently became more and more aware of the fact that they often need to study their source materials more independently from the distinctions made between traditional categories of sources that have been developed mainly by nineteenth-century typologies, SMLC will serve new research needs very well. ${ }^{25}$ With one single query it will become possible to collect, for instance, all the diplomatic and narrative sources regarding the Benedictine abbeys of the diocese of Liège in the twelfth century. Or for a palaeographer, it will become possible to compare the handwriting of a charter available on Diplomatica Belgica with that of a reproduction of a manuscript cross-referenced by Narrative Sources.

In sum, the SMLC project, which will require a development phase of approximately three years and the recruitment of both a historian and an IT-specialist, has a threefold aim: (1) making available electronically the rich collection of Diplomata Belgica in a way which perfectly coincides with our current research interests and needs; (2) completely updating the contents Narrative Sources, and (3) developing a multiple database system for both these collections in order to facilitate combined searches

\footnotetext{
${ }^{24}$ In the terminology of IT-specialists this module will rely upon an architecture consisting of a presentation layer (user interfaces), application layers (business logic) and a database layer (data sources and databases). Data integration will be done in an application layer. This approach guarantees that users can enter their combined searches via the presentation layer. These searches will be processed in the application layer and broken down into sub-queries that will be submitted to the individual databases. Each individual query will be processed by its corresponding database system in the database layer. Next, the individual query results will be sent to the application layer which will combine the results in an overall answer set to the combined search. Finally, the overall answer will be submitted to the presentation layer for presentation to the user.

25 The importance of this new approach was also argued recently by N. MAzEuRE, $U t$ ipsius privilegii testatur karta, quam etiam hic inscribere curavimus, uti tunc factam accepimus. Oorkondingspraktijk, archiefbeheer en benedictijnse abdijhistoriografie in de Zuidelijke Nederlanden (10de-12de eeuw) (Antwerp: unpublished doctoral dissertation, 2008).
} 
and advanced methods of 'data mining' and information retrieval with a view to future research questions. Hence it is hoped that within a few years, the project Sources from the Medieval Low Countries (SMLC) will stimulate the development of several new directions in medieval studies and that it will remain a most innovative heuristic tool for many years to come. 